HARRAN ÜNIVERSITESI MÜHENDISLIK DERGisi

HARRAN UNIVERSITY JOURNAL OF ENGINEERING

e-ISSN: 2528-8733

\section{HARRAN ÜNIVERSITESİ MÜHENDISSLIKK DERGİSI}

HARRAN UNIVERSITY JOURNAL of ENGINEERING

e-ISSN: 2528-8733 (ONLINE)

URL: http://dergipark.gov.tr/humder

Dalgacık Dönüşüm Modelli Yapay Zekâ Teknikleri Kullanılarak Orta Anadolu Bölge İstasyonlarının Yağış Tahmini

Precipitation Prediction of Central Anatolia Regional Stations Using Artificial Intelligence Techniques with Wavelet Transform Model

Yazarlar (lar) (Author(s)): Hatice ÇITAKOĞLU ${ }^{1}$, Ömer COŞKUN $N^{2}$

${ }^{1}$ ORCID ID: 0000-0001-7319-6006

${ }^{2}$ ORCID ID: 0000-0002-4222-8754

Bu makaleye şu şekilde atıfta bulunabilirsiniz (To cite to this article): Çıtakoğlu H., Coşkun Ö., "Dalgacık Dönüşümm Modelli Yapay Zekâ Teknikleri Kullanılarak Orta Anadolu Bölge İstasyonlarının Yağış Tahmini", Harran Üniversitesi Mühendislik Dergisi, 6(1): 39-54, (2021).

Erişim linki (To link to this article): http://dergipark.gov.tr/humder/archive 


Mühendislik Dergisi

Araştırma Makalesi

\title{
Dalgacık Dönüşüm Modelli Yapay Zekâ Teknikleri Kullanılarak Orta Anadolu Bölge İstasyonlarının Yağış Tahmini
}

\author{
Hatice ÇITAKOĞLU ${ }^{1, *}$, Ömer COŞKUN ${ }^{2}$ \\ ${ }^{1 * E r c i y e s ~ U ̈ n i v e r s i t e s i, ~ M u ̈ h e n d i s l i k ~ F a k u ̈ l t e s i, ~ I ̇ n s ̧ a a t ~ M u ̈ h e n d i s l i g ̆ i ~ B o ̈ l u ̈ m u ̈, ~ 38220, ~ M e l i k g a z i / K A Y S E R I ̇ ~}$ \\ ${ }^{2}$ Devlet Su İsleri Genel Müdürlügü, 12.Bölge Müdürlü̆̈̈̈, Kocasinan/KAYSERİ
}

$\ddot{O} z$

Makale Bilgisi

Başvuru: 07/09/2020

Yayln: $30 / 04 / 2021$

\section{Anahtar Kelimeler}

Yă̆ıs

Tahmin

Dalgactk Dönüşümü

USBÇS

YSA

\section{Keywords}

Precipitation

Prediction

Wavelet transform

ANFIS

$A N N$
Meteorolojik koşullarda önemli bir parametre olan yağış verilerinin belirlenmesi; tarım, enerji, çevre, ulaşım, lojistik ve afet kontrolü gibi birçok sektörü doğrudan etkilemektedir. Geleceğe yönelik yağış verilerinin doğru tahmin edilmesi, özellikle insanların günlük hayatını kolaylaştıracaktır. Önceki dönemlere ait yağış verilerinin kullanılması, gelecek dönemlerin yağış tahminlerine ve erken uyarı sistemlerinin kurulmasına olanak sağlayacaktır. Bu çalışmada, Türkiye'nin Orta Anadolu Bölgesi istasyonlarının 1990-2015 yılları arasındaki aylık toplam yağış verileri kullanılarak geleceğe yönelik yağış tahminleri yapılmıştır. Yağış tahmini için iki farklı yaklaşımda bulunulmuştur. Bu yaklaşımlardan ilki, önceki dönemlere ait istasyonların aylık toplam yağış verilerine sadece yapay sinir ağ çıkarım sisteminin (ANFIS) uygulanmasıdır. Diğer yaklaşım ise dalgacık dönüşüm modelinin hem YSA hem de ANFIS'e uygulanmasıdır. Bu modellerde 1990-2009 yılları arasındaki aylik toplam yağış verileri eğitim verileri olarak, 2010-2015 yılları arasındaki veriler ise test verileri olarak kullanılmıştır. Yağış verileri $\mathrm{t}-2$ ve $\mathrm{t}-1$ zamanları için giriş verisi olarak kullanılmış olup t zamanındaki yağışlar tahmin edilmeye çalıșılmıştır. Bu modellerin tahmin performansları, determinasyon katsayısı gibi istatistiksel kriterlere göre değerlendirilmiştir. Determinasyon katsayısına (0.011 ile 0.189) göre yağış verilerine YSA ve ANFIS metotları uygulanması ile yapılan tahminler kötü sonuçlar vermektedir. Determinasyon katsayısına göre Dalgacık dönüşümlü YSA (DD-YSA) ve dalgacık dönüşümlü ANFIS (DD-ANFIS) modelleri ise geleceğe dönük yağış verilerinin tahmininde daha başarılıdır. Ayrıca bu çalışmada ortaya çıkan önemli sonuçlardan biri de istatistiksel kriterlere göre DD-ANFIS ve DD-YSA modellerinin birbirine çok yakın sonuçlar vermesidir.

\section{Precipitation Prediction of Central Anatolia Regional Stations Using Artificial Intelligence Techniques with Wavelet Transform Model}

\begin{abstract}
Determination of precipitation data, which is an important parameter in meteorological conditions; it directly affects many sectors such as agriculture, energy, environment, transportation, logistics and disaster control. Correct prediction of future precipitation data will make the daily life of people easier, especially. Using rainfall data from previous periods will allow precipitation forecasts for future periods and establishment of early warning systems. In this study, Turkey's Central Anatolia Region stations rainfall predictions for the future are made using monthly total precipitation data from 1990-2015 year. Two different approaches have been taken for precipitation predictions. The first of these approaches is to apply only artificial neural network (ANN) and adaptive neural fuzzy inference system (ANFIS) to monthly total precipitation data of stations belonging to previous periods. Another approach is to apply the wavelet transform model to both ANN and ANFIS. In these models, monthly total precipitation data between 1990 and 2009 were used as training data, and data between 2010 and 2015 were used as test data. Precipitation data were used as input data for times $t-2$ and $t-1$, and precipitation at time $t$ was tried to be predicted. The prediction performances of these models
\end{abstract}


were evaluated according to statistical criteria such as determination coefficient. According to the coefficient of determination (0.011-0.189), the predictions made by applying ANN and ANFIS to the precipitation data give bad results. According to the coefficient of determination, ANN with wavelet transform (WT-ANN) and ANFIS with wavelet transform (WT-ANFIS) models are more successful in predicting future precipitation data. In addition, one of the important results of this study according to statistical criteria is that the WT-ANN and WT-ANFIS models give very similar results to each other.

\section{GİRIŞ (INTRODUCTION)}

Suyun dünyanın en faydalı kaynağı olduğu konusunda tereddüt bulunmamakla birlikte dünyada susuz yaşayabilecek hiçbir insan ve canlı da yoktur. Yaşam döngüsünün devam edebilmesi için bu eşsiz kaynağa her şeyden daha çok ihtiyaç duymaktayız. Ancak bu değerli kaynak, yeryüzünün artan 1sısı ve küresel 1sınmaya bağlı iklim koşulları nedeniyle hızlı bir şekilde tükenmektedir. Bu nedenle insanoğluna düşen en önemli görevlerden biri suyun mevcut ve gelecekteki durumunu, miktarını ve kalitesini iyi bir öngörü ve planlama ile değerlendirerek gerçekçi politikalar üretmektir. İşte bu noktada yağış tahminlerinin ne kadar önemli bir çalışma alanı olduğu daha belirgin bir şekilde ortaya çıkmaktadır. Yağış tahmini, gelişen teknoloji ve yenilik dünyasında bilimsel alanlarda popüler bir araştırma olarak son yıllarda önemli bir yer tutmaktadır. Çünkü yağışın sadece insan hayatı üzerinde değil, bir bütün olarak ekonomiler ve canlılar üzerinde de büyük etkileri söz konusudur. Çeşitli yapay zekâ teknikleri kullanılarak yağış tahmini üzerine daha önce birçok çalışmalar yapılmış olup bu yöntemlerin tüm artı ve eksileri detaylı analiz edilmiştir. Araştırmacılar yapay zekâ teknikleri ile yağış tahmini yapma konusunda daha mükemmel ve daha doğru sonuçlar elde edebilmek için hala büyük bir uğraş içerisindedirler [1].

Yağış tahmini modellerini deneysel ve dinamik olmak üzere iki ana başlık altında toplamak mümkündür. Deneysel yaklaşımlar genellikle tarihi bazlı ve aralarında önemli ölçüde ilişki bulunan verilere dayanan metotlardır. Bunlardan en önemlileri yapay sinir ağları (YSA), stokastik modeller, bulanık mantık ve veri tabanlı grup modelleridir. Dinamik yaklaşımlar ise iklimsel şartların ve atmosferde meydana gelen değişimlerin bir araya getirilerek oluşturulan denklem takımlarına dayanmaktadır [2].

Yağış başta olmak üzere hidrometeorolojik tahminlerde son yıllarda diğer alanlarda olduğu gibi yapay zekâ tekniklerinin kullanımı oldukça popülerdir. YSA, bilinen hesaplama tekniklerinden farklı olarak, elde eksik bilgi olsa dahi bulunduğu ortama uyum sağlayarak, kararlar verebilen ve hatalara karş1 toleranslı ve başarılı sonuçlar elde edebilen bir hesaplama yöntemidir. YSA'nın kullandığı öğrenme algoritmaları, bilinen bilgisayar algoritmaları dışında insan sezgilerini temel alır. Bu işlevi, girdi ve çıktıları sisteme tanıtıp öğrenme ortamı oluşturarak ve bu ortamda eğitme işlemleriyle, verilerinin sınıflandırılmasını sağlayarak gerçekleştirir [3]. İnsan beyninin bilgi işleme tekniğinden esinlenerek geliştirilen ve doğrusal olmayan hesaplama yaklaşımı olan YSA, karmaşık hidrolojik sistemleri modellemek için de etkili yöntemlerden biri olarak kabul edilmiştir. YSA yöntemi, hidrolojik değişkenlerin tahmininde yaygın olarak kullanılmasına rağmen, kararlı olmayan verilerin tahmininde yeterince hassas ve güvenilir sonuçlar vermeyebilir. Bu sebeple doğrusal olmayan ilişkiler içeren hidrolojik zaman serilerinin tahmininde, YSA'nın performansını artırmak için veri ön işleme tekniklerinin kullanılması ihtiyacı doğmuştur [4].

Uyarlamalı Sinirsel Bulanık Çıkarım Sistemi (ANFIS) ise içerisindeki çeşitli algoritmaları uygulayarak, geçmiş dönem verileri üzerinden sistemin bir çıkarım yapmasını sağlayan ve bu işlemler sonucu elde edilen tahmin değerlerini kıyaslayarak, en iyi sonucu elde etmeye çalışan bir yapay zekâ tekniğidir. Bu nedenlerden dolayı tahmin çalışmalarında bu yöntemler oldukça sık kullanılır. ANFIS, istenilen sonuçları ve çıktıyı elde etmek için işlemleri basitleştirmeyi ve karmaşıklığını azaltmayı amaçlamaktadır. ANFIS verileri işlemek için nöronları kullanır, nöronlar da düğüm noktaları olarak çalışır. ANFIS, her bir işlemin gelecekteki operasyonları için veri ve bilgileri depolayan bir dizi kural sunar. Girilen kurallar, girdi ve çıktılara bağlıdır. Çıktıları elde etmek için yaygın olarak uygulanan bir alan bilgisi mevcuttur. Çıktı, 
güncelleme parametrelerine ve bunların koleksiyonlarına bağlıdır. ANFIS, farklı optimizasyon tekniklerine göre kuralı yönlendirir [5].

Küçük ve Ağıralioğlu [6], dalgacık dönüşümü tekniğini hidrolojik akım serilerinin tahmininde kullanmışlardır. İlk olarak sürekli dalgacık dönüşümü ve global spektrum yardımı ile ölçüm serileri analiz edilmiştir. İki ayrı ölçüm istasyonuna ait akarsu akım serileri ayrık dalgacık dönüşümü uygulanarak bileşenlerine ayrılmıştır. Modelde tahmin eden ve tahmin ettirici değişkenler yerine akım serilerinin ayrık dalgacık dönüşümü bileşenleri kullanılmıştır. Ayrık dalgacık dönüşümü kullanılan akım modellerinin birçok hata kriterine göre daha başarılı sonuçlar verdiği görülmüş̧ür. Partal ve Kişi [7], yağış tahmini için yeni bir birleştirme yöntemi (dalgacık ile sinirsel-bulanık modeli) önermişlerdir. Türkiye'deki 3 istasyonun gözlemlenen günlük yağışları, ayrık dalgacık dönüşümü kullanılarak bazı alt serilere ayrıştırılmış ve daha sonra günlük yağış tahminlerinde sinirsel-bulanık modellere girdi olarak uygun alt seriler kullanılmıştır. Dalgacık ve sinirsel-bulanık modeli, özellikle yaz aylarında sıfır yağış alan zaman serileri ve test dönemindeki pikler için gözlemlenen verilere iyi bir uyum sağlanmıştır. Model sonuçlarına göre birleştirme yöntemi klasik sinirsel-bulanık yöntemine göre daha iyi sonuçlar vermiştir. Partal ve ark.[8], YSA ve dalgacık dönüşümü yöntemleri ile günlük yağış tahmini üzerine bir çalışma yapmışlardır. Bu çalışmada, Türkiye'ye ait 3 istasyonun günlük meteorolojik verileri kullanılmıştır. YSA yönteminin literatür de en çok kullanılan algoritmalarından, İleri Beslemeli Geriye Yayılmalı Yapay Sinir Ağları (IBGYSA) ve Radyal Tabanlı Yapay Sinir Ağları (RTYSA) yöntemleri yağış tahmini amacıyla kullanılmıştır. Sonuçlarda İBGYSA algoritmasının kullanıldığı yöntem en iyi performansı göstermiştir. Dalgacık dönüşümü-YSA (DD-YSA) yönteminin tahmin sonuçları da çoklu lineer regresyon yönteminin sonuçları ile kıyaslanmış ve performans kriterlerine göre daha iyi olduğu bulunmuştur. Saplığlu ve Çimen [9], YSA yöntemini kullanarak yağış tahmini için bir model geliştirmişlerdir. Bu model, Amerika Birleşik Devletlerinin Portland bölgesinde bulunan 121, 120, 21 ve 107 no'lu yağış gözlem istasyonlarında ölçülmüş günlük yağış verilerine uygulanmıştır. Modelleme, 2000-2009 yılları arasında her bir istasyondan alınan 3170 adet günlük yağış verisi için uygulanmıştır. Elde edilen sonuçlar literatürde mevcut olan ağırlıklı ve harmonik ortalama metotlarından elde edilen sonuçlar ile karşılaştırılmıştır. Bozoğlu ve Baran [10], dalgacık dönüşümü tekniğini kullanarak Gediz havzasında bulunan ve DMİ tarafından işletilen Akhisar istasyonunun 1937-2005 yılları arası aylık toplam yağış değerlerinin değişimlerini incelemişlerdir. Dalgacık dönüşümü ile belirlenen yağış verilerinin diğer klasik dönüşüm yöntemleri ile tespiti zor olan periyodik yapısı ve bu yapının zamansal eğilimi araştırılmıştır. Dalgacık dönüşümü ile gürültüleri azaltılarak oluşturulan yağış verilerinde yaklaşık $\% 95$ oranında güvenilir bir eğilim elde edilmiştir. Terzi ve Barak [11], Kızılırmak Nehri'nde bulunan Sögütlühan akım istasyonuna ait akım tahmin modelleri geliştirmek için Sivas meteoroloji istasyonuna ait yağış verilerini kullanmışlardır. İlk olarak ölçülmüş orijinal yağış serileri kullanılarak YSA modelleri geliştirilmiştir. Daha sonra, ölçülmüş yağış değerleri dalgacık dönüşümü ile alt serilere ayrılmıştır. Yağış alt serileri ile dalgacık-yapay sinir ağı (D-YSA) modelleri geliştirilmiştir. Geliştirilen modeller ölçülmüş değerlerle kıyaslandığında, dalgacık dönüşümü uygulandıktan sonra elde edilen D-YSA modellerinin, orijinal serilerle elde edilen YSA modellerinden daha iyi performans sergilediği görülmüsstür. Uzunali [12], çalışmasında Kandilli Rasathanesi ve Deprem Araştırma Enstitüsü Müdürlüğünün, Kandilli Bölgesine ait Ocak 1918 ile Aralık 2018 yılları arasındaki 100 yıllık veri arşivini kullanarak önceki yıllara dayalı son yılların ortalama yağış değerlerinin tahminini yapmıştır. Yağış tahmininde; YSA yöntemlerinden Uyarlamalı Sinirsel Bulanık Çıkarım Sistemi (ANFIS) modeli kullanılmıştır. Analize hazırlanan veriler kümelenerek hedef bir değerin, hangi kümeye ait olduğu belirlenmiş ve bunun için ANFIS üyelik fonksiyonlarının hata toleransları karşılaştırılmıştır. En iyi sonucu veren üyelik fonksiyonuyla yağış tahmini gerçekleştirilmiştir. Yapay sinir ağlarının su kaynaklarında başka geniş uygulama alanları da vardır. Üneş ve ark. [13, 14], yaptıkları çalışmalarda ABD'deki Alabama'da bulunan Millers Ferry Barajının günlük rezervuar seviyesini ve Massachusetts’taki Stony Brook Barajının rezervuar kapasitesini yapay sinir ağ 1 (YSA) modellerini kullanarak tahmin etmişlerdir. Optimum YSA model sonuçlarını geleneksel çoklu doğrusal regresyon (ÇDR) model sonuçları ile karşılaştırmışlardır. Modeller ortalama karesel hata $(\mathrm{OKH})$, ortalama mutlak hata $(\mathrm{OMH})$ ve determinasyon katsayısı $\left(\mathrm{R}^{2}\right)$ kriterlerine göre karşılaştırılmıştır. Karşılaştırma sonuçlarına göre YSA modellerinin ÇDR modellerine göre daha iyi performanslar gösterdiği görülmüştür. 
Bu çalışmanın amac1; Türkiye'nin Orta Anadolu Bölgesinde yer alan Kayseri (17196), Nevşehir (17193) ve Aksaray (17192) Meteoroloji İstasyonlarının 1990-2015 yılları arasındaki aylık toplam yağış verilerini kullanarak orijinal YSA ve ANFIS ile dalgacık dönüşümlü YSA ve ANFIS modelleri üzerinden bu istasyonların geleceğe yönelik yağış değerlerinin tahmin edilmesidir. Bu modellerde; 1990-2009 yılları arasındaki aylık yağış verileri eğitim verisi, 2010-2015 yılları arasındaki veriler ise test verisi olarak kullanılmıştır. Yağış verileri $\mathrm{t}-2$ ve $\mathrm{t}-1$ zamanları için giriş verisi olarak kullanılmış olup $\mathrm{t}$ zamanındaki yağışlar tahmin edilmeye çalışılmıştır. Ayrıca bu çalışmada ayrık dalgacık dönüşüm modelinin diğer yapay zekâ teknikleri ile birlikte kullanıldığı takdirde tahmin çalışmalarında nasıl bir etkisinin olacağı da incelenmek istenmiştir.

\section{MATERYAL VE METOT}

\section{1. Çalışma Alanı}

Bu çalışmada; Türkiye'nin Orta Anadolu Bölgesinde yer alan Kayseri (17196), Nevşehir (17193) ve Aksaray (17192) Meteoroloji İstasyonlarının 1990-2015 yılları arasındaki aylık toplam yağış verileri kullanılmıştır. İstasyonlara ait yağış verileri Meteoroloji Genel Müdürlüğünden temin edilmiştir. Tablo 1'de meteoroloji istasyonları ile ilgili bilgiler verilmiştir. Şekil 1'de ise istasyonların Türkiye'deki ve bölgedeki konumları verilmiştir.

Tablo 1. Meteoroloji İstasyon Bilgileri

\begin{tabular}{|c|c|c|c|c|c|c|}
\hline $\begin{array}{c}\text { İstasyon } \\
\text { Numarası }\end{array}$ & İstasyon Adı & Yer & $\begin{array}{c}\text { Gözlem } \\
\text { Süresi }\end{array}$ & Enlem & Boylam & Rakım \\
\hline 17196 & Kayseri & Merkez & $1990-2015$ & $38^{\circ} 41^{\prime} 13^{\prime \prime}$ & $35^{\circ} 30^{\prime} 00^{\prime \prime}$ & 1054 \\
\hline 17193 & Nevşehir & Merkez & $1990-2015$ & $38^{\circ} 36^{\prime} 58^{\prime \prime}$ & $34^{\circ} 42^{\prime} 09^{\prime \prime}$ & 1224 \\
\hline 17192 & Aksaray & Merkez & $1990-2015$ & $38^{\circ} 22^{\prime} 13^{\prime \prime}$ & $33^{\circ} 59^{\prime} 55^{\prime \prime}$ & 980 \\
\hline
\end{tabular}

Kaynak:MGM Web Sitesi-Erişim Eylül 2020.https://www.mgm.gov.tr/ 


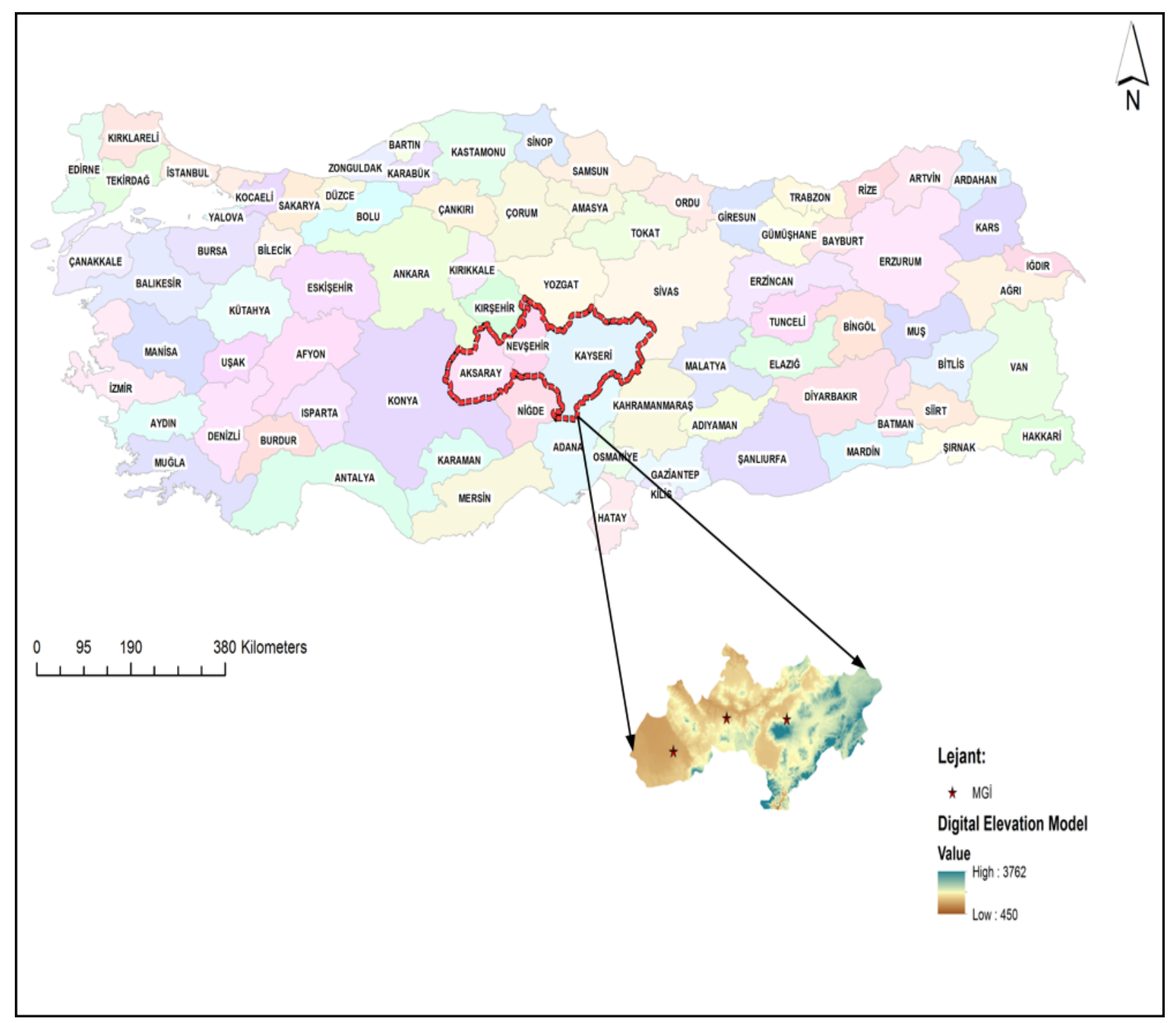

Şekil 1. Kayseri, Nevşehir ve Aksaray Meteoroloji İstasyonlarının Türkiye ve Bölgedeki Konumu

\subsection{Mann-Whitney Homojenlik Testi}

Bir serinin tüm elemanlarının aynı olasılık dağılımına uyup uymadığını kontrol etmek için yaygın olarak kullanılan bir testtir. İlk olarak, seri $\mathrm{p} \leq \mathrm{q}(\mathrm{p}+\mathrm{q}=\mathrm{n})$ olacak şekilde iki eşit parçaya bölünür ve daha sonra orijinal seri artan sırada sıralanır. İkinci olarak, serinin ilk yarısının sıra numaralarının toplamı hesaplanır ve $S$ ile gösterilir. Üçüncüsü, Mann-Whitney'in $U$ istatistiği aşağıdaki gibi hesaplanan $V$ ve W değerlerinden daha küçük olanıdır:

$$
\begin{gathered}
\mathrm{V}=\mathrm{S}-[\mathrm{p} \times(\mathrm{p}+1)] / 2 \\
\mathrm{~W}=\mathrm{p} \times \mathrm{q}-\mathrm{V}
\end{gathered}
$$

Burada, U normal dağılımdır. Bu nedenle standartlaştırılmış değişkenin kuyruk olasıllığı kritik olasılığın yarısından büyükse, seri homojen olarak kabul edilir [15].

\subsection{Yapay Sinir Ăgları (YSA)}

Yapay Sinir Ağları (YSA), bilgisayar dünyasından insan beyninin ve sinir sisteminin davranışlarını taklit etme esası üzerine kurulmuş yeni bir bilgi işleme yaklaşımıdır. İnsan beyninin taklit edilmesi ile ortaya çıkan bu yapılar her ne kadar nanosaniyeler içerinde işlemleri yerine getirebilme kapasiteli olsa da insan 
beyninin milisaniyeler düzeyindeki işlevsel hızına hala ulaşamamıştır. Yapay sinir ağları, biyolojik sinir ağlarının karakteristiklerine benzer şekilde çalışan bir bilgi işleme sistemidir. Basit işlem birimlerinden oluşan, deneyimsel bilgileri biriktirmeye yönelik doğal bir eğilimi olan ve bunların kullanılmasını sağlayan yoğun bir şekilde paralel dağıtılmış bir işlemcidir. YSA beyne iki yönüyle benzemektedir. Birincisi, bilgiyi öğrenerek elde eder. İkincisi ise nöronlar arası ağırlıklar; bilgiyi sağlamak için kullanılır. YSA'ların sahip olduğu öğrenme yeteneği, kolaylıkla farklı problemlere uyarlanabilirliği, öğrenme işleminden sonra daha az bilgiye gereksinim duyması, genelleme yapabilme yeteneği, paralel yapılarından dolayı hızlı işlem yapabilmeleri ve zor matematiksel modelleri oldukça hızlı çözebilmeleri gibi sahip oldukları özellikleri nedeniyle birçok farklı alanda başarıyla uygulanmaktadır [16]. Bir yapay sinir hücresi; girdiler, ağırlıklar, toplam fonksiyonu, aktivasyon fonksiyonu ve çıktı olmak üzere beş ana kısımdan oluşur. Girdiler, diğer hücrelerden ya da dış ortamlardan hücreye giren bilgilerdir. Ağırlıklar, girdi kümesi veya kendinden önceki bir tabakadaki başka bir işlem elemanının bu işlem elemanı üzerindeki etkisini ifade eden değerlerdir. Toplam fonksiyonu girdiler ve ağırlıkların tamamının bu işlem elemanına etkisini hesaplayan bir fonksiyondur. Bu fonksiyon bir hücreye gelen net girdiyi hesaplar[11].

Bu çalışma, YSA yöntemini MATLAB programına ait hazır kodlar kullanılarak tamamlanmıştır. Aşağıda MATLAB programına ait YSA kodları mevcuttur.

net $=$ newff([minmax $(\mathrm{P} 1)],[\mathrm{k} 1],\{$ 'logsig"tansig' $\}$, 'trainlm')

net=train(net,P1,T1)

$\mathrm{Y} 1=\operatorname{sim}($ net,P1)

\subsection{Uyarlamalı Sinirsel Bulanık Çıkarım Sistemi (ANFIS)}

ANFIS, yapay sinir ağları ile bulanık mantığın bir arada bulunduğu kombine bir yöntemdir. ANFIS, girdi-çıktı ilişkisini tanımlamak ve girdi yapısını belirleyerek bulanık kuralları oluşturmak için YSA'nın öğrenme yeteneğini kullanır. Sistem sonuçları, bulanık mantığın düşünme ve muhakeme kabiliyeti ile elde edilmiştir. Karma öğrenme algoritması ve çıkarma işlevi, girdi yapısını belirlemek için kullanılır. Jang tarafından 1990'ların başında geliştirilmiştir. Bu yöntemde adaptif ağa sunulan girdi değerlerine karşılık çıktı değerlerinin belirlenmesinde üyelik fonksiyonları ile eğer-ise şeklinde oluşturulan bulanık kurallar hesaba katılır. ANFIS giriş ve çıkış değerlerini optimize ederken, öğrenme algoritması olarak en küçük kareler yöntemi ile geri yayılmalı öğrenme algoritmasından oluşan melez öğrenme algoritmasını kullanır. İleri besleme yönteminde giriş değerleri sabit kalırken çıkış değerleri en küçük kareler yöntemiyle hesaplanırken geri beslemede ise çıkış değerleri sabitken, giriş değerleri geri yayılmalı öğrenme algoritmasıyla hesaplanır [17].

$\mathrm{Bu}$ çalışma, ANFIS yöntemini MATLAB programına ait hazır kodlar kullanılarak tamamlanmıştır. Aşağıda MATLAB programına ait ANFIS kodları mevcuttur.

mfType = str2mat('trimf,'trimf,',trimf,',trimf')

in_fis = genfis1(data,numMFs,mfType,'constant')

[out_fis, RMSE, stepsize] = anfis(data,in_fis,[2,0.0005,0.02,0.9,1.1], [1, 1, 1, 1], [], 1)

\subsection{Wavelet (Dalgacık) Dönüşümü Modeli}

Ön işleme tekniklerinden biri olan dalgacık dönüşümü, yaklaşık 25-30 yıl önce matematikçiler tarafindan ortaya atılmış bir sinyal işleme tekniğidir. Tarihsel gelişim yönünden dalgackk dönüşümü yeni kullanılmaya başlanmış bir yöntem olup temeli Joseph Fourier'e kadar uzanmaktadır. Fourier dönüşümünün tersine, dalgacık dönüşümü ile her bir zaman aralığında sinyalin hem alçak hem de yüksek frekans bileşenlerini hesaplamak mümkündür. Bu yöntemle, frekansı zamanla değişen sistemlerin analizi ve geçici durum analizleri oldukça hassas bir şekilde yapılmaktadır [18]. 
Bir fonksiyonu veya sinyali başka bir biçime dönüştürme, orijinal sinyalin belirli özelliklerini çalışmaya daha uygun hale getirme ya da orijinal veri setinin daha kısa ve öz bir şekilde tanımlanması için kullanılır. Dalgacık dönüşümü bir sinyali bir dizi temel fonksiyona ya da dalgacıklara ayrıştırır. Wavelet (dalgacık) dönüşümünün en önemli parametresi dalgacıktır. Dalgacık terimi, küçük dalga anlamında dalgacık olarak ifade edilir. Bir fonksiyonun dalgacık olabilmesi, süresinin sınırlı ve ortalama değerinin sıfır olması koşullarına bağlıdır. Bu nedenle dalgacık fonksiyonu genlik ekseninin pozitif ve negatif yönlerinde salınım yapmalı ve bu salınım, zaman ekseninde ilerledikçe genlik ekseninde sıfıra oturarak sona ermelidir. Dalgacık nitelik yönünden ele alınacak olursa aşağıdaki iki koşulu sağlayan bir gerçek değerli $\psi(\mathrm{x})$ fonksiyonu olmasi gerekir [19].

Dalgacığın ortalaması sıfırdır:

$$
\int_{-\infty}^{+\infty} \Psi(x) d x=0
$$

Varyans değeri (genlik değerlerinin karelerinin toplamı) ise sonludur.

$$
\int_{-\infty}^{+\infty} \Psi^{2}(x) d x=1
$$

\subsubsection{Ayrık Dalgacık Dönüşümü}

Dalgacık katsayılarının ölçek değerlerinde hesaplanması çok miktarda katsayının oluşmasına ve işlem yüküne neden olduğundan dolayı, katsayıların yalnızca seçilen ölçekler ve zaman dilimleri için hesaplanması birçok avantajlar sağlar. En çok kullanılan ölçek adımı ikilik ölçek ve zaman adımıdır. Seçilmiş yeni ölçek değerleri ile yeniden ifade edilen ve ayrık dalgacık dönüşümü için kullanılan dalgacık fonksiyonu, aşağıdaki bağıntıda verilmiştir.

$$
\psi_{m, n}\left(\frac{t-\tau}{s}\right)=s_{0}^{-m / 2} \psi\left(\frac{t-n \tau_{0} s_{0}{ }^{m}}{s_{0}{ }^{m}}\right)
$$

Burada m ve n tamsayı olarak dalgacığın sırası ile ölçek ve zaman eksenindeki ötelenme parametreleridir. $\mathrm{s}_{0}$, sabit bir ötelenme adımını ifade eder ve değeri 1'den büyüktür, $\tau_{0}$ zaman eksenindeki ötelenme aralığ1 değeridir. Yukarıdaki denklemde zaman eksenindeki ötelenme adımı $S_{0}{ }^{m}$ değerine bağlı olarak $n \tau_{0} s_{0}{ }^{m}$ şeklinde ifade edilebilir. En sık kullanılan $\mathrm{s}_{0} \mathrm{ve} \tau_{0}$ değerleri 2 ve 1'dir. Bileşenlere ayırma işlemi ardışık tekrar ederek sinyali istenilen çözünürlük seviyesinde bileşenlere ayırmak mümkün olmaktadır. Ardışık tekrarlama işlemi Şekil 2'de gösterilmiştir.

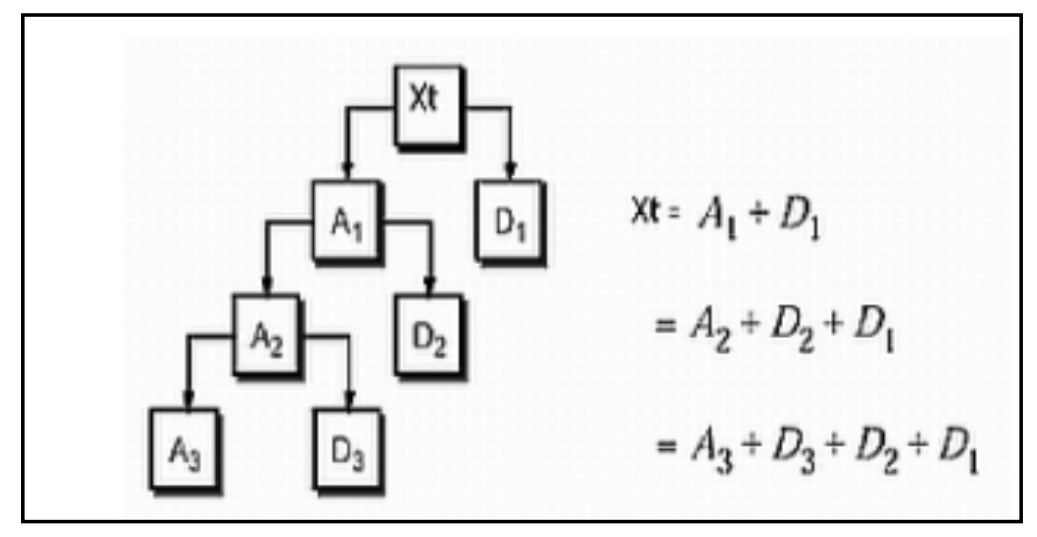

Şekil 2. Ardışık ayrışma işlemi 
Orijinal $x(q)$ işareti önce yüksek geçirgen $g(q)$ filtresinden ve alçak geçirgen $h(q)$ filtresinden geçirilir. Burada zaman ( $\mathrm{t}$ ) tam sayı şeklinde alınır ve $\mathrm{q}$ şeklinde gösterilmiştir. Bu bir seviyeli bir ayrıştırma işlemidir ve matematiksel olarak şöyle ifade edilebilir.

$$
\begin{aligned}
& y_{\text {yüksek }}(k)=\sum_{n} x(q) \cdot g(2 k-q) \\
& y_{\text {alçak }}(k)=\sum_{n} x(q) \cdot h(2 k-q)
\end{aligned}
$$

Burada $y_{y u ̈ k s e k}(k)$ ve $y_{\text {alçak }}(k), 2$ ile alt örneklemenin ardından sırasıyla yüksek geçirgen ve alçak geçirgen filtre çıkışlarıdır. $\mathrm{k}$ ise filtre seviyesidir. Birçok işaret için en önemli kısım düşük frekanslı bileşenlerdir. $\mathrm{Bu}$ su kaynakları alanında mevsimsel değişimler veya bölgenin iklimsel karakterini ortaya koyan dönemsel değişimleri ifade eder. Düşük periyotlu yüksek frekanslı bileşenler ise daha çok ani değişen taşkın gibi karakterleri yansıtır [6].

\subsection{Verilerin Normalizasyonu}

YSA ve ANFIS'in en belirgin özelliklerinden olan doğrusal olmama özelliğini anlamlı kılan yaklaşım, verilerin normalizasyon işlemidir. Veriler ağa sunulmadan önce normalizasyon işlemine tabi tutulurlar. $\mathrm{Bu}$ işlem verideki aşırı salınımları engellemek ve sistem performansını arttırmak için kullanılır. Çünkü normalizasyon işlemi giriş verileri transfer edilirken fonksiyonun aktif olan bölgesinden aktarılmasını sağlar. Genellikle verilerin $[0,1]$ veya $[-1,1]$ aralıklarından birine ölçeklenmesi önerilmektedir.

Veri kümesinin $[0,1]$ arasında bir ölçeklendirilmeye tabi tutulabilmesi için o kümenin $X_{\min }-X_{\max }$ aralığ1 bulunur ve aşağıdaki formüle göre ölçeklendirme yapılır.

$$
\mathrm{X}_{\mathrm{nor}}=\left(\mathrm{X}-\mathrm{X}_{\min }\right) /\left(\mathrm{X}_{\max }-\mathrm{X}_{\min }\right)
$$

\subsection{Model Performansının Belirlenmesi}

Model sonuçları, karekök ortalama karesel hata $(\mathrm{KOKH})$, ortalama mutlak hata $(\mathrm{OMH})$ ve determinasyon katsayısı $\left(\mathrm{R}^{2}\right)$ kriterlerine göre karşılaştırılmıştır. Bunlardan KOKH ve OMH değerleri 0'a yaklaştıkça, $\mathrm{R}^{2}$ değeri ise 1'e yaklaştıkça daha doru ve güvenilir tahminlerin yapıldığı anlaşılmaktadır. KOKH ve OMH değerleri aşağıdaki gibi hesaplanır:

$$
\begin{array}{r}
K O K H=\sqrt{\frac{1}{N} \sum_{i=1}^{N}\left(P_{\text {tahmin }, i}-P_{\text {ölçülen }, i}\right)^{2}} \\
O M H=\frac{1}{N} \sum_{i=1}^{N}\left|P_{\text {tah } \min , i}-P_{\text {ollçulen }, i}\right|
\end{array}
$$

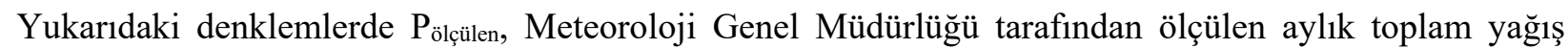
değerlerini; $\mathrm{P}_{\text {tahmin, }}$ yapay zekâ yöntemleri ile tahmin edilen aylık yağış değerlerini ve $\mathrm{N}$ ise örnek uzunluğunu ifade etmektedir. Regresyon sürecinde hesaplanan determinasyon katsayısı $\left(\mathrm{R}^{2}\right)$, tahmin ve ölçülen yağış değerlerinin arasındaki ilişkinin doğrusal bir eğriye ne kadar uyduğunun bir ölçüsüdür. $\mathrm{R}^{2}$ değerinin 1'e eşit olması doğrusal bir eğri sağlanarak modelin mükemmel olduğunu gösterir. Determinasyon katsayısı $\left(\mathrm{R}^{2}\right)$ aşağıdaki gibi hesaplanır:

$$
R^{2}=1-\frac{\sum_{i=1}^{N}\left(P_{\text {ollsülen }, i}-P_{\text {tah } \min , i}\right)^{2}}{\sum_{i=1}^{N}\left(P_{\text {tah } \min , i}-\overline{P_{\text {tah } \min }}\right)^{2}}
$$


Yukarıdaki denklemde $\overline{P_{\text {tahmin }}}$ yapay zekâ yöntemleri ile tahmin edilen aylık yağış değerlerinin ortalamasını ifade etmektedir.

\section{BULGULAR ve TARTIŞMA}

Türkiye'nin Orta Anadolu Bölgesinde yer alan Kayseri (17196), Nevşehir (17193) ve Aksaray (17192) Meteoroloji İstasyonlarına ait yağış verilerine YSA ve ANFIS yöntemleri uygulanmadan önce üç istasyonun homojenliği araştırılmıştır. Üç istasyona ait aylık toplam yağış verilerine Mann-Whitney Homojenlik testi uygulanmıştır. Tablo 2'de görüleceği üzere Mann-Whitney Homojenlik testi sonucunda üç meteoroloji istasyonu homojen çıkmıştır.

Tablo 2. Ü̧̧ Meteoroloji istasyonuna ait Mann-Whitney Homojenlik Testi sonuçları

\begin{tabular}{|l|l|l|l|}
\hline & MWstatistic & phesap & pcri \\
\hline AKSARAY & 12391.0 & 0.390 & 0.025 \\
\hline NEVSEHII & 12392.5 & 0.389 & 0.025 \\
\hline KAYSERI & 12461.5 & 0.356 & 0.025 \\
\hline
\end{tabular}

Türkiye'nin Orta Anadolu Bölgesinde yer alan Kayseri (17196), Nevşehir (17193) ve Aksaray (17192) Meteoroloji İstasyonlarının 1990-2015 yılları arasındaki aylık toplam yağış verileri sadece YSA ve sadece ANFIS modelleri ile dalgacık dönüşümlü YSA (DD-YSA) ve dalgacık dönüşümlü ANFIS (DD-ANFIS) modellerine istasyonların gelecek yağış değerlerini tahmin edebilmek amacıyla uygulanmıştır. Yağış verileri $\mathrm{t}-2$ ve $\mathrm{t}-1$ zamanları için giriş verisi olarak kullanılmıştır. $\mathrm{t}-2$ ve $\mathrm{t}-1$ zamanlarının seçilmesinde herhangi zaman serisi kurallarına dikkat edilmemiş olup dalgacık dönüşümü ve YSA-ANFIS birleştirilmesi ile YSA ve ANFIS'in tahmin etme gücündeki artış1 vurgulamaktır. $\mathrm{t}-4$ ve t-3gibi girdi sayısının artırılması ile giriş sayısının artmasından dolayı determinasyon katsayısında artış beklenmekte olup buda dalgacık dönüşümünün etkisinin gözlenmemesine neden olacaktır. İstasyonların 1990-2009 yılları arası yağış verileri eğitim, 2010-2015 yılları arası yağış verileri ise test verisi olarak seçilmiştir.

$\mathrm{Bu}$ çalışmada; yağış tahmininde kullandığımız YSA modellerinin tamamı için çok katmanlı YSA modelleri ele alınmış olup giriş ve çıkış katmanları arasında kullanılan aktivasyon fonksiyonları giriş için tanjant sigmoid transfer fonksiyonu (tansig) ve logaritmik sigmoid transfer fonksiyonu (logsig), çıkış için ise lineer transfer fonksiyonu (pürelin) aktivasyon fonksiyonu olarak seçilmiştir. Öğrenme algoritması olarak da standart sayısal optimizasyon tekniklerinden biri olan ve son dönemde çok kullanılan Levenberg Marquardt (LM) öğrenme algoritması kullanılmıştır. 1 gizli katmanlı modelde nöron sayısı $2-3$ ve $1-100$ aralığında iterasyon sayısı deneme-yanılma yapılarak en düşük hata kriterini veren model tespit edilmiştir.

Yağış tahmini çalışmamızda kullandığımız bir diğer yaklaşım olan ANFIS için de yine aynı girdi ve çıtı değişkenleri ele alınmıştır. Üyelik fonksiyonları olarak gaussian (gaussmf) ve üçgen (triangular-trimf) fonksiyonları seçilmiştir. Ağa ait çıkış fonksiyonları olarak da sabit (constant) ve doğrusal (linear) olmak üzere toplam iki çeşit fonksiyon belirlenmiş olup 1 ve 5 arasında değişen iterasyon sayıları denenmiştir. Modelden en iyi sonuçları elde etmek için giriş ve çıkış üyelik fonksiyonlarından 4 farklı kombinasyon ile2-3 üyelik sayısı değiştirilerek sonuçlar karşılaştırılmıştır.

DD-YSA ve DD-ANFIS modellerinde ise ayrık dalgacık dönüşümü tercih edilmiştir. Orijinal yağış verileri, daubechies-10 dalgacık ailesi kullanılarak sadece 3. seviyeden dalgacık bant katsayıları belirlenerek daha alt bileşenlerine ayrılmıştır. $\mathrm{Bu}$ frekans bileşenlerinin her biri yeniden YSA ve ANFIS'te eğitilmişlerdir. Eğitilen her bir frekans bileşeni toplanarak yağış tahminleri elde edilmiştir. Tüm bu analizler MATLAB adlı matematiksel yazılımda yapılmıştır. MATLAB yazılımında YSA ve ANFIS kodları, kolay ve pratik bir şekilde çalışmaktadır. 
$\mathrm{Bu}$ çalışmanın birinci aşamasında YSA ve ANFIS modellerinde $\mathrm{t}-2$ ve $\mathrm{t}-1$ zamanlardaki yağış verileri giriş verisi alınarak t zaman diliminde yağış verileri tahmin edilmiştir. Tablo 3, 4 ve 5 'te YSA ve ANFIS modelleri ile elde edilen her bir istasyonun geleceğe yönelik yağış tahmin sonuçları KOKH, OMH ve $\mathrm{R}^{2}$ kriterlerine göre karşılaştırılmıştır. Tablo 3, 4 ve 5'te görüleceği üzere bütün istasyonlarda KOKH ve OMH değerleri kabul edilebilir düzeydedir. Fakat bu çalışmada YSA ve ANFIS modelleriyle elde edilen $\mathrm{KOKH}$ ve $\mathrm{OMH}$ değerlerinin düşük olması yanıltıcıdır. Bu çalışmada modellerin performansı $\mathrm{R}^{2}$ kriteri ile karşılaştırılması daha sağlıklı yorum yapılmasını sağlar. Tablo 3, 4 ve 5'e göre istasyonların eğitme ve test sonuçlarına bakıldığında YSA modelinin $\mathrm{R}^{2}$ değerleri 0.011 ile 0.189 aralığında olup oldukça düşüktür. $\mathrm{Bu}$ sonuçlar orijinal YSA modelinin tahmin başarısının oldukça düşük olduğunu göstermektedir. Aynı zamanda Tablo 3, 4 ve 5'e göre istasyonların eğitme ve test sonuçlarına bakıldığında ANFIS modelinde determinasyon katsayısının 0.014 ile 0.150 değerleri arasında olduğu görülmektedir. Bu sonuçlar doğrultusunda YSA ve ANFIS modellerinin tahmin etme konusunda başarısız olduğu aşikârdır.

$\mathrm{Bu}$ çalışmanın ikinci aşamasında orijinal yağış verileri ayrık dalgacık dönüşümü ile daubechies-10 dalgacık ailesi kullanarak sadece 3. seviyeden dalgacık bant katsayıları belirlenmiştir. Hesaplanan düşük ve yüksek frekans bileşenlerinin her biri $\mathrm{t}-2$ ve $\mathrm{t}-1$ zamanlardaki bileşenleri giriş verisi olarak kullanılarak YSA ve ANFIS'te eğitilir. Yapay zekâ yöntemleri ile eğitilen her bir frekans bileşeni toplanarak tahmini yağış verisi elde edilir. Tablo 3,4 ve 5 'te her bir istasyona ait DD-YSA ve DD-ANFIS modelleri ile elde edilen her bir istasyonun geleceğe yönelik yağış tahmin sonuçları KOKH, $\mathrm{OMH}$ ve $\mathrm{R}^{2}$ kriterleri mevcuttur. Tablo 3, 4 ve 5'te görüleceği üzere $\mathrm{DD}-\mathrm{YSA}$ ve DD-ANFIS modellerinin $\mathrm{OMH}$ ve KOKH değerleri YSA ve ANFIS modellerinin OMH ve KOKH değerlerinin yaklaşık yarısına eşittir. Tablo 3, 4 ve 5'e göre istasyonların eğitme ve test sonuçlarına bakıldığında DD-YSA modelinde $\mathrm{R}^{2}$ değeri 0.739 ile 0.834 değerleri aralığında çıkmıştır. Aynı zaman tablolara göre DD-ANFIS modelinde ise $\mathrm{R}^{2}$ değeri 0.754 ile 0.823 değerleri aralığında çıkmıştır. Şekil 3-8'e göre tahmin ve ölçülen yağış değerlerinin arasındaki ilişkinin doğrusal bir eğriye yaklaştı̆̆ 1 görülecektir. Bu sonuçlar YSA ya da ANFIS modellerine bağlı tahminlerin başarılı sonuçlar vermediğini, DD-YSA ve DD-ANFIS modellerinin tahmin etme konusunda daha başarılı olduğunu göstermektedir. Aynı zamanda DD-YSA ile DD-ANFIS modelleri de birbirlerine çok yakın sonuçlar vermektedir.

Tablo 3.Kayseri Meteoroloji İstasyonunun KOKH, OMH ve Re performans kriterlerine göre eğitim ve test sonuçlarının karşılaştırması

\begin{tabular}{|l|c|c|c|c|c|c|}
\hline \multirow{2}{*}{$\begin{array}{l}\text { KAYSĔLIŞ - } \\
\text { YAĢ }\end{array}$} & \multicolumn{3}{|c|}{ EĞİTME VERISI } & \multicolumn{3}{c|}{ TEST VERÍSI } \\
\cline { 2 - 7 } & KOKH & OMH & $\mathbf{R}^{\mathbf{2}}$ & KOKH & OMH & $\mathbf{R}^{\mathbf{2}}$ \\
\hline ANFIS & 24.00 & 19.15 & 0.121 & 27.35 & 21.42 & 0.130 \\
\hline DD-ANFIS & 10.81 & 8.39 & 0.823 & 14.37 & 11.72 & 0.756 \\
\hline YSA & 23.44 & 18.44 & 0.161 & 28.39 & 22.70 & 0.073 \\
\hline DD-YSA & 10.44 & 7.97 & 0.834 & 14.43 & 11.56 & 0.755 \\
\hline
\end{tabular}


Tablo 4. Nevşehir Meteoroloji İstasyonunun KOKH, OMH ve $R^{2}$ performans kriterlerine göre eğitim ve test sonuçlarının karşılaştırması

\begin{tabular}{|l|c|c|c|c|c|c|}
\hline \multirow{2}{*}{$\begin{array}{l}\text { NEVŞEHİR - } \\
\text { YAĢ }\end{array}$} & \multicolumn{3}{|c|}{ EĞITME VERISI } & \multicolumn{3}{c|}{ TEST VERISI } \\
\cline { 2 - 7 } & KOKH & OMH & R $^{\mathbf{2}}$ & KOKH & OMH & $\mathbf{R}^{\mathbf{2}}$ \\
\hline ANFIS & 24.98 & 19.17 & 0.150 & 31.06 & 24.10 & 0.043 \\
\hline DD-ANFIS & 11.74 & 8.99 & 0.814 & 15.37 & 12.20 & 0.754 \\
\hline YSA & 25.25 & 19.14 & 0.131 & 32.04 & 24.97 & 0.011 \\
\hline DD-YSA & 11.96 & 9.21 & 0.806 & 15.44 & 11.92 & 0.753 \\
\hline
\end{tabular}

Tablo 5. Aksaray Meteoroloji Istasyonunun KOKH, OMH ve $R^{2}$ performans kriterlerine göre eăitim ve test sonuçlarının karşılaştırması

\begin{tabular}{|l|c|c|c|c|c|c|}
\hline \multirow{2}{*}{$\begin{array}{l}\text { AKSARAYSIŞ } \\
\text { YAY }\end{array}$} & \multicolumn{3}{|c|}{ EĞITTE VERİSI } & \multicolumn{3}{c|}{ TEST VERISİ } \\
\cline { 2 - 7 } & KOKH & OMH & $\mathbf{R}^{\mathbf{2}}$ & KOKH & OMH & $\mathbf{R}^{\mathbf{2}}$ \\
\hline ANFIS & 21.29 & 16.51 & 0.140 & 28.09 & 34.20 & 0.014 \\
\hline DD-ANFIS & 10.17 & 7.74 & 0.808 & 13.36 & 10.93 & 0.777 \\
\hline YSA & 20.66 & 16.09 & 0.189 & 26.80 & 21.04 & 0.074 \\
\hline DD-YSA & 10.53 & 8.03 & 0.794 & 14.19 & 11.02 & 0.739 \\
\hline
\end{tabular}

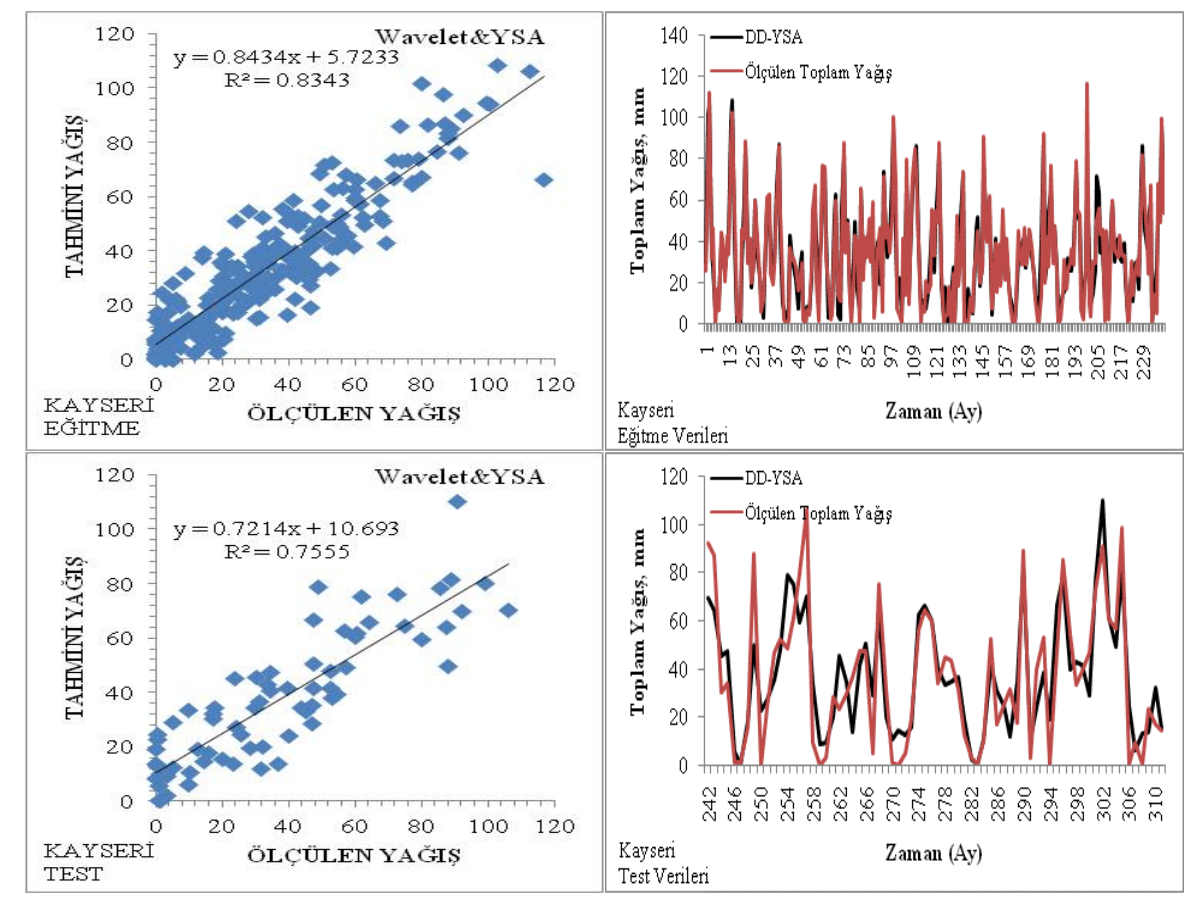

Şekil 3. Kayseri Meteoroloji İstasyonunun DD-YSA modeli için eğitme ve test sonuçlarının grafiksel gösterimi 


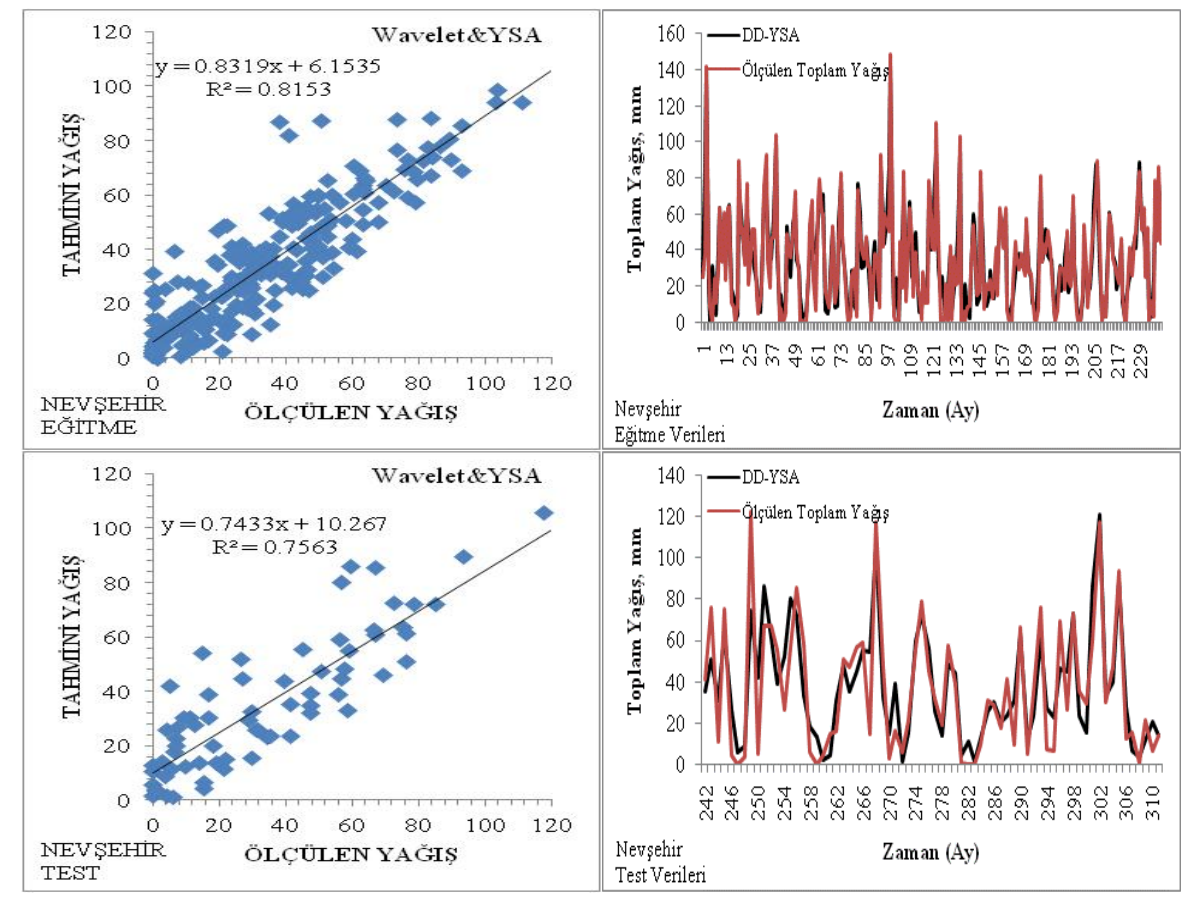

Şekil 4. Nevşehir Meteoroloji İstasyonunun DD-YSA modeli için eğitme ve test sonuçlarının grafiksel gösterimi

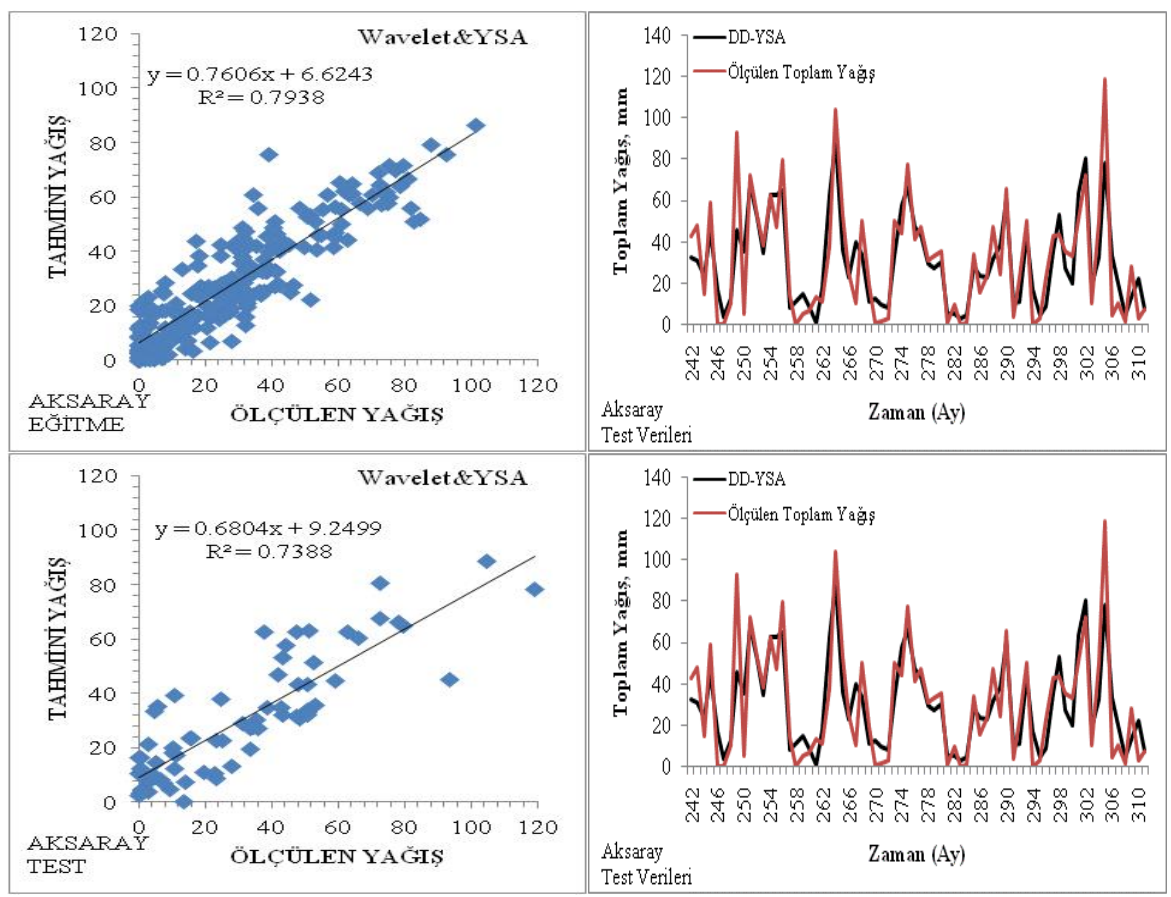

Şekil 5. Aksaray Meteoroloji İstasyonunun DD-YSA modeli için eğitme ve test sonuçlarının grafiksel gösterimi 


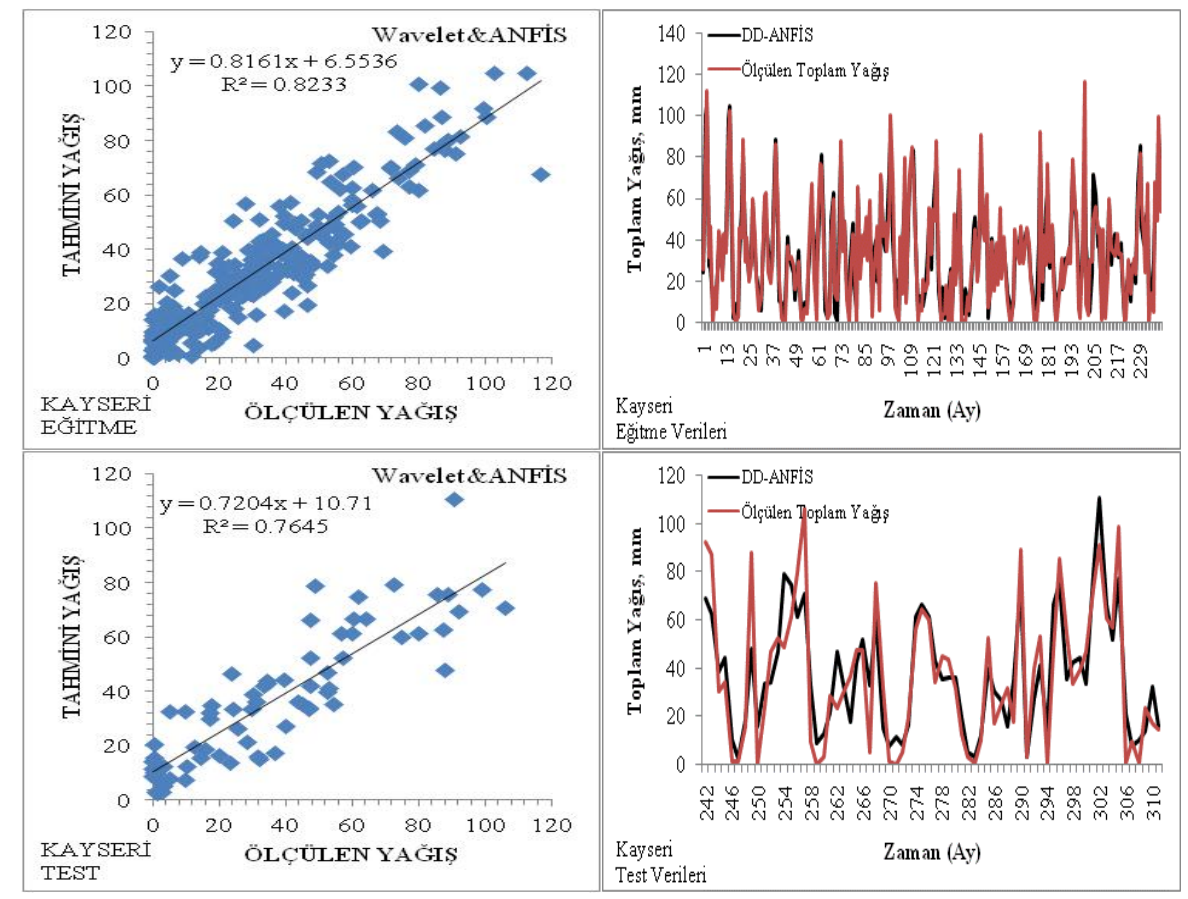

Şekil 6. Kayseri Meteoroloji İstasyonunun DD-ANFIS modeli için eğitme ve test sonuçlarının grafiksel gösterimi

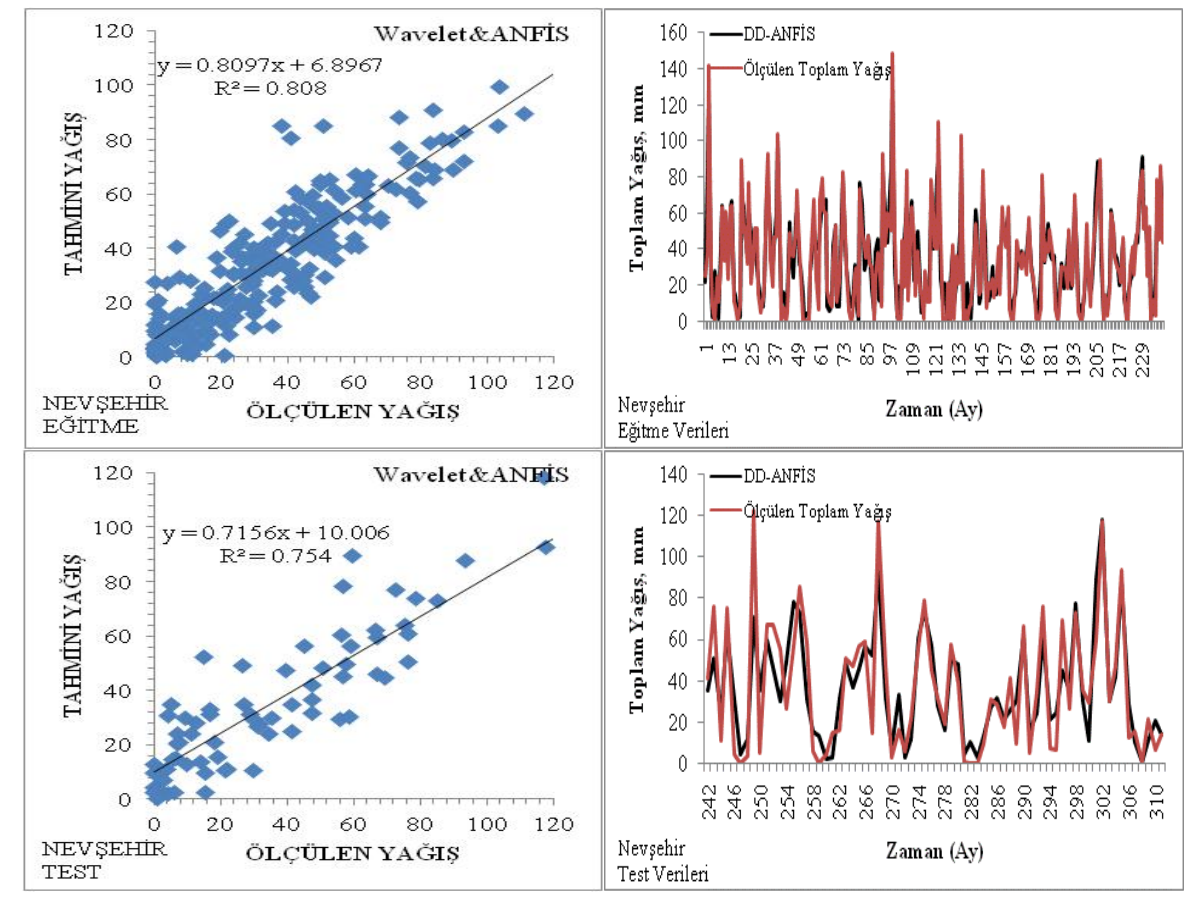

Şekil 7. Nevşehir Meteoroloji İstasyonunun DD-ANFIS modeli için eğitme ve test sonuçlarının grafiksel gösterimi 


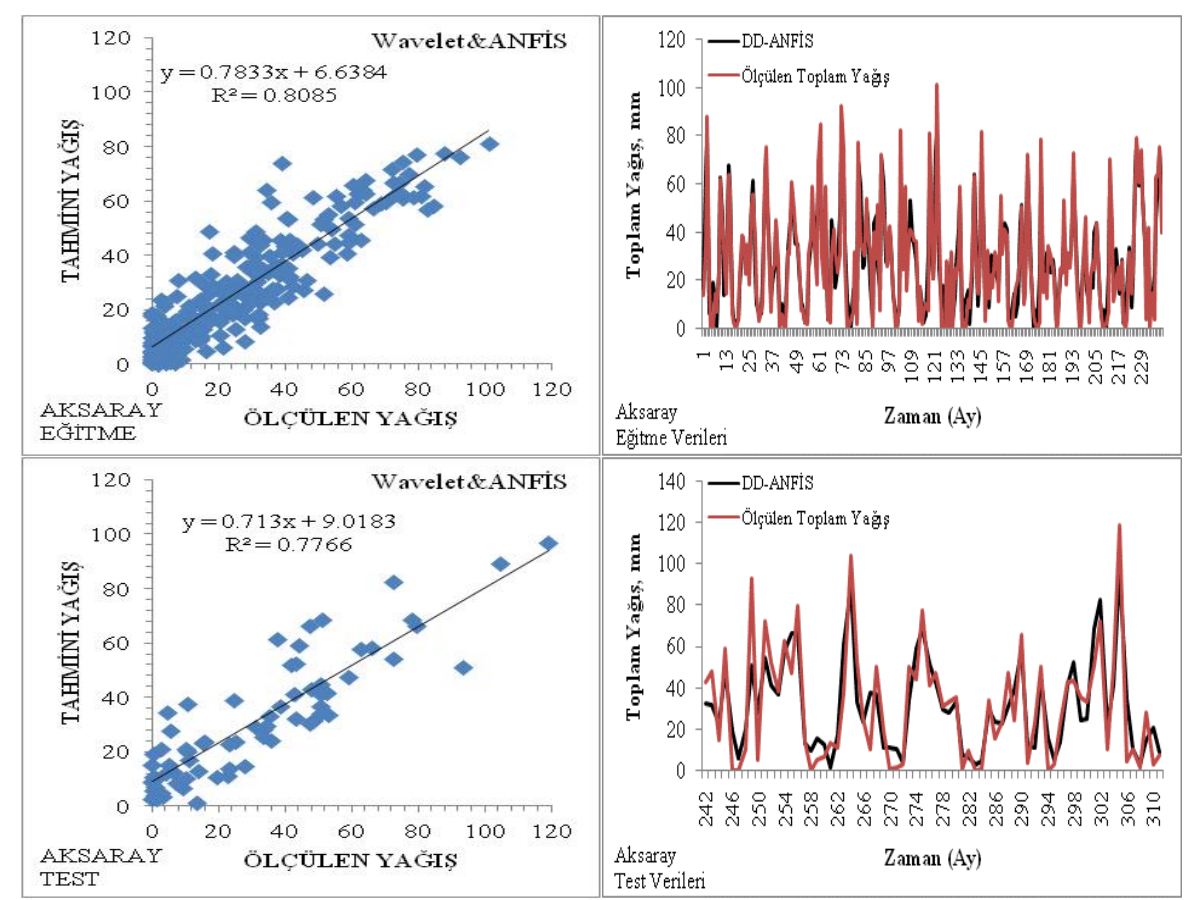

Şekil 8. Aksaray Meteoroloji İstasyonunun DD-ANFIS modeli için eğitme ve test sonuçlarının grafiksel gösterimi

\section{SONUÇ (CONCLUSION)}

Yağış başta olmak üzere hidrometeorolojik veriler hayatımızın büyük bir kısmında önemli yer tutmaktadır. Bu verilerin tarihi kayıtları ve zaman içerisindeki eğilimleri geleceğe yönelik olarak bizlere önemli ipuçları vermektedir. Bu veriler ne kadar sağlıklı bir şekilde ele alınıp çeşitli tekniklerle de desteklenirse o kadar doğru ve güvenilir analizler elde edilir. Hidrometeorolojik verilerin geleceğe dönük doğru analizi yaşamı bizler için daha öngörülebilir ve konforlu hale getirecektir. Bu yüzden gelecek durum projeksiyonlarının daha doğru bir şekilde oluşturulabilmesi için tahmin çalışmalarına da ayrı bir önem vermek gerekir. Yapay zekâ teknikleri ile oluşturulan tahmin modelleri klasik yöntemlere göre daha kısa sürede ve daha geniş perspektifte sonuçlar vermektedir. Herhangi bir dönem veya herhangi bir bölge için oluşturulan modeller bu teknikler sayesinde başka dönemler veya başka bölgeler için de uygulanabilmektedir.

Çalışmada ele alınan Türkiye'nin Orta Anadolu Bölgesinde, son yıllarda iklim değişikliği ve küresel 1sınma nedeniyle yağış rejiminde ciddi manada olumsuz bir görüntü ortaya çıkmaktadır. Mevcut durumda dahi Türkiye yağış ortalamasının çok altında bulunan bu bölgede yağış üzerine çalışmaların daha da yoğunlaşması ve geleceğe yönelik projeksiyonların oluşturulması elzemdir. Ayrıca bu tarz çalışmaların neticesinde yerel veya bölgesel eylem planları oluşturulabileceği gibi erken uyarı sistemleri de rahatlıkla kurulabilecektir.

Orta Anadolu Bölgesinde bulunan Kayseri (17196), Nevşehir (17193) ve Aksaray (17192) Meteoroloji İstasyonlarının 1990-2015 yılları arasındaki aylık toplam yağış verileri kullanılarak oluşturulan 4 farklı model (YSA, ANFIS, $D D$-YSA ve $D D$-ANFIS) üzerinden bu istasyonların geleceğe yönelik yağış değerleri tahmin edilmeye çalışılmıştır. İstasyonların $\mathrm{t}-1$ ve $\mathrm{t}-2$ zamanlarındaki yağış verileri giriş verileri olarak modellere tanıtılmıştır. Bilindiği üzere yapay zekâ teknikleri ile oluşturulan modellerde sisteme ne kadar çok veri girişi yapılırsa model bunları daha çok eğiterek daha çok teste tabi tutacaktır. Çalışmamızda 1990-2015 yılları arasındaki istasyonların yağış verileri değerlendirilmiştir. Bundan sonraki yapılacak çalışmalarda veri setinin daha uzun periyotlu seçilmesi durumunda daha sağlıklı ve daha başarılı tahminler elde edilebilecektir. Çalışmamızda oluşturduğumuz modellerin performansları; 
karekök ortalama karesel hata $(\mathrm{KOKH})$, ortalama mutlak hata $(\mathrm{OMH})$ ve determinasyon katsayısı $\left(\mathrm{R}^{2}\right)$ kriterlerine göre değerlendirilmiştir. YSA ve ANFIS modellerinin eğitim ve test sonuçları ele alındığında özellikle $\mathrm{R}^{2}$ değerlerinin çok küçük (0.043-0.189) değerlerde çıktığ 1 görülmüştür. Ancak bu modellere dalgacık dönüşümünün eklenmesiyle birlikte $D D$-YSA ve $D D$-ANFIS modellerinin eğitim ve test sonuçları ele alındığında $\mathrm{R}^{2}$ değerlerinin (0.739-0.834) daha anlamlı ve daha doğru değerlere ulaştığ1 görülmüştür. Ayrıca $D D$-YSA ve $D D$-ANFIS modellerinin performansları birbirine oldukça yakın çıkmıştır. Bu sonuçlardan hareketle yapay zekâ teknikleri ile yapılan tahmin çalışmalarında sadece bir model ya da yöntem üzerinden gidilmesinin çok doğru ve güvenilir olmayacağı, çalışmanın doğruluğunu ve güvenilirliğini artırmak için o model ya da yöntemin yanına veri setini daha küçük boyutlarda ve ayrıntıda ele alabilecek dalgacık dönüşümü gibi başka bir yöntemin de uygulanabileceği kolaylıkla söylenebilir.

\section{TEŞEKKÜR (ACKNOWLEDGMENTS)}

Çalışmamızda kullanmış olduğumuz Kayseri, Aksaray ve Nevşehir Meteoroloji İstasyonlarının yağış verilerini temin etmemizde bizlere çok büyük katkısı olan Meteoroloji Genel Müdürlüğü çalışanlarına en içten teşekkürlerimizi sunarız.

\section{ÇIKAR ÇATIŞMASI (CONFLICT OF INTEREST)}

Makale yazarları aralarında herhangi bir çıkar çatışması olmadığını beyan ederler.

\section{KAYNAKLAR (REFERENCES)}

[1] S. K. Biswas, L. Marbaniang, B. Purkayastha, M. Chakraborty, H. R. Singh, \& M. Bordoloi, Rainfall forecasting by relevant attributes using artificial neural networks a comparative study. International Journal of Big Data Intelligence, 3: 2 (2016) 1-10.

[2] T. Partal, Türkiye yağış miktarlarının yapay sinir ağları ve dalgacık dönüşümü yöntemleri ile tahmini, Doktora tezi, İTÜ Fen Bilimleri Enstitüsü, İstanbul, 2007.

[3] E. Öztemel, Yapay Sinir Ağları, Papatya Yayıncılık, Ankara, 2012.

[4] U. Okkan, Wavelet neural network model for reservoirin flow prediction. Scientia Iranica 19: 6 (2013) $1445-1455$.

[5] I. Wahyuni, W. F. Mahmudy, \& A. Iriany, Rainfall prediction using hybrid adaptive neuro fuzzy inference system (ANFIS) and genetic algorithm. Journal of Telecommunication, Electronic and Computer Engineering, 9: 2-8 (2017): 1-6.

[6] M. Küçük, N. Ağıralioğlu, Dalgacık dönüşüm tekniği kullanılarak hidrolojik akım serilerinin modellenmesi. İTÜ Mühendislik Dergisi, 5: 2 (2006) 69-80.

[7] T. Partal, Ö. Kişi, Wavelet and neuro-fuzzy conjuction model for precipitation forecasting. Journal of Hydrology, 342: 1-2 (2007) 199-212.

[8] T. Partal, E. Kahya, K. Cığızoğlu, Yağış verilerinin yapay sinir ağları ve dalgacık dönüşümü yöntemleri ile tahmini. İstanbul Teknik Üniversitesi Dergisi-Mühendislik 7: 3 (2008) 73-85.

[9] K. Saplığlu, M. Çimen, Yapay sinir ağlarını kullanarak günlük yağış miktarının tahmini. Mühendislik Bilimleri ve Tasarım Dergisi, 1: 1 (2010) 14-21. 
[10] Ö. Bozoğlu, T. Baran, Yağış serilerinin (wavelet) dalgacık dönüşümü ile analizi, VII. Ulusal Hidroloji Kongresi, 26-27 Eylül 2012, Süleyman Demirel Üniversitesi, Isparta, 1: 1 (2012) 1-10.

[11] Ö. Terzi, M. Barak, Dalgacık-sinir ağı yaklaşımı ile yağış-akış tahmini: Kızılırmak Nehri örneği. Ankara Üniversitesi Ziraat Fakültesi Tarım Bilimleri Dergisi, 21: 2015 (2013): 546-557.

[12] A. Uzunali, Yapay sinir ağlarına dayalı yağıș tahmin ve analizi, Yüksek Lisans Tezi, İstanbul Kültür Üniversitesi Fen Bilimleri Enstitüsü, İstanbul, 2019.

[13] F. Üneş, M. Demirci, Generalızed regression neural networks for reservoir level modeling. International Journal of Advanced Computational Engineering and Networking, 3: 8 (2015) 81-84.

[14] F. Üneş, M. Demirci, T. Bestami, H. Varçin, Estimation of dam reservoir volume using neural networks. Air and Water-Components of the Environment Conference Proceedings, Cluj-Napoca, Romania, 1: 1 (2020) 191-200.

[15] A. R. Rao, and K. H. Hamed, Flood frequency analysis. 1.8. tests on hydrologic data, CRC, Boca Raton, FL, 2000.

[16] H. Citakoglu, Comparison of artificial intelligence techniques for prediction of soil temperatures in Turkey. Theoretical and Applied Climatology, 130:1 (2017): 545-556.

[17] S. B. Özen, Kaski atık su arıtma verilerinin yapay sinir ağları ve bulanık mantık yöntemleri ile tahmin edilmesi, Yüksek Lisans Tezi, Erciyes Üniversitesi Fen Bilimleri Enstitüsü, Kayseri, 2018.

[18] Ö. Coşkun, S. Çömlekçi, Wavelet teorisinin medikal alana uygulanması üzerine bir ön çalışma. Akademik Bilişim 07 - IX. Akademik Bilişim Konferansı, 31 Ocak - 2 Şubat 2007, Dumlupınar Üniversitesi, Kütahya, 1: 1 (2007) 317-320.

[19] V. Öner, M. Yeşilyurt, E. Yılmaz, Wavelet analiz tekniği ve uygulama alanları. Ordu Üniv. Bil. Tek. Dergisi, 7: 1 (2017) 42-56. 